\title{
Geopolitical Interstices: Social Risk Determinants
}

\author{
Gabriel Justo Saucedo-Arteaga \\ National Institute of Medical Sciences and Nutrition
}

The interstice is a space where three or more states, or municipalities, converge, with low: accessibility, development and natural resources; social conflicts and instability. Interstices with conflicts can be identified: bordering, agrarian, socio-environmental; armed groups, drug trafficking and in indigenous regions, among others.

This concept has been constructed based on macro ethnographic studies (participant observation) in regions of the Estado de Mexico and la sierra Tarahumara; previous investigations and news of local conflicts. It uses the official cartography, about: social backwardness, poverty, marginalization, indigenous population, human development and criminality.

The interstices have economic and geographical conditions, but the political will and responsibility is unavoidable. They seem to be "no man's land" or empty spaces of power, because they do not represent an economic or political interest for the State; on the contrary, they do facilitate the development of capital and factual power groups that evade corrupt laws or regulations and put the population at risk.

Keywords: territory, ethnography, conflicts, socio/environmental, indigenous regions

\section{INTRODUCTION}

For the social sciences, the natural environment or geographical space is made up of orography, natural resources and ecosystems; elements that in their unity are to some extent under the influence of human capacity and interest. The material totality, like the territory, is the set of resources, ecosystems and natural environments that societies inhabit, occupy, dispute, use, appropriate, administer and symbolize in a given demarcation. For this reason, the general field of study of geography is not material space, but rather that of the relationships that human groups establish there (León, 2016: 73).

Geopolitical space is an empirically verifiable social, historical and material fact that can be used, occupied and transformed by human societies. This space is a historical-dialectic process due to the relations of human groups. In this study we will refer to the geopolitical space and its units of analysis and observation, such as the national territory, the state and the municipality. In each unit there are different institutional responses, social, economic or political responsibilities; they are regulated by the corresponding political-administrative constitution and under the control of the State.

The study of the conditions/determinants of the social and health risks proposes initially to know the prevalence and distribution of the disease or risk in a determined space-time. This approach is based on a fundamental epidemiological principle: risks and diseases are not randomly distributed; rather, there are 
conditions and determinants that increase or reduce those risks. These conditions can be social, economicenvironmental, and many more. Just as health risks are not randomly distributed, neither do other less social phenomena occur randomly, such as conflicts, ecological disasters, armed uprisings, among others.

Risk-from the social science perspective-, is a construction closely related to vulnerability ${ }^{1}$ and inequality (García, 2005). It is largely conditioned by human practices, environmental degradation, urbanization processes, demographic dynamics and socioeconomic inequalities. Risks and damages are multidimensional and multifactorial processes that are developed over time (Oliver, 2002). In this work, we consider social risk as the process of recreating social conditions of accumulated and differential vulnerability/inequality-fragile and susceptible contexts that increase the negative effects of isolation, conflict, exploitation, disease, poor nutrition, violence, poverty, and adverse environmental and geographic conditions.

In this paper we aim to elaborate the concept of geopolitical interstice and try to test the hypothesis that geopolitical interstices are likely to exist in any state.

\section{BACKGROUND}

The study of social problems in relation to spaces, political and economic regions has a great tradition in Mexico; the works of Manuel Orozco y Berra, Apuntes para la historia de la geografía en México e ideas de las divisiones territoriales de México (1881) (Notes for the history of geography in Mexico and ideas of the territorial divisions of Mexico (1881)), as well as Historia de las divisiones territoriales de México (1985) (History of the territorial divisions of Mexico (1985)), by Edmundo O'Gorman, are enough to have an overview of the subject about the territorial division and the historical process of the entities.

In scientific research there were attempts to analyze the characteristics of the population from a geographic determinism, ${ }^{2}$ which culminated in a positivist human ecology (Barth, 2004). In Mexico, the most frequent reference has been the use of the concept of region since Manuel Gamio (Comas, 1975). With this background, Gonzalo Aguirre Beltrán later elaborated the concept of regions of refuge. Carmen Viqueira and Guillermo de la Peña, among others, have also widely discussed the concept of region. In medicine, epidemiology and public health, medical geography is a classic and fundamental resource. On the other hand, in the economy there is a whole school initiated by the works of Angel Bassols (1979) and his economic regions of Mexico. Based on this work, a group of experts has been formed around geography, rural and regional development. The National Commission for the Development of Indigenous Peoples (CDI) uses the concept of indigenous region, which is essentially socio-political, and its purpose is political action (INI, 1993; Viqueira, 2001: 163). Although regionalization implies that this space is shared with other historical, economic, linguistic, cultural characteristics and that there is geographical continuity, this does not mean that the space is closed and unchanged. It is important to develop new concepts for the spatial analysis of social problems, which also contribute to decision making.

\section{PROBLEM STATEMENT}

In the Mexican geography, the socioeconomic and political processes that condition the health and well-being of the population have a certain regularity among the states, regions, municipalities and localities. For example, the health system has a structure, organization and operation that allow it to provide preventive services, family medicine or high specialty medicine in any state, even when each one has different types of problems and conditions. In fact, this regularity of services and the control of the territory are a means of legitimizing the State. Despite this, it is possible that there are spaces (geopolitical interstices) where relations between people and social groups are exposed to a dynamic of greater risk of social instability. The existence of interstices can be of high social risk, which is why it poses some situations of responsibility and commitment. What are the characteristics of interstices? What conditions or determines the existence of interstices? Have these spaces always existed or how do they develop? What institutions and political actors can contribute to the development or elimination of these spaces? What are the social risks that can occur in these spaces? 
Geographic conditions and features may be identified as obstacles to the distribution of resources, goods or services due to poor accessibility and limited means of communication in certain regions. However, risks cannot be attributed to geographical determinism, even in cases of disaster. On the contrary, from another perspective, we consider of greater importance the social history (experience) of the communities and their vertical-horizontal relationships with the political, social and economic structures (De la Peña, 1997).

The above is based on the assumption that the State and its institutions must attend to the needs and interests of the groups they claim to represent.

\section{METHODOLOGY}

\section{Data Collection and Analysis}

To demonstrate the dynamics and changes of the limits of the territory, the historical cartography of the national territory was used. The two great moments taken as reference are the unsettled Mexico and the current Mexico, although reference is made to the Federation's Constitutive Acts of 1824, 1857 and 1917. The field study was of ethnographic type to describe and analyze the cases, based on the participant observation and in situ tours. With the data obtained in ethnography, the variables for the operational definition of the interstices were selected. Background information on social conflicts was obtained from written sources: research, magazines and newspapers; border conflicts: socio-environmental, agrarian in indigenous regions; armed conflicts: drug trafficking and crime. In order to test the hypothesis that there are geopolitical interstices in a federal state, cartography on the distribution of social prayer, food poverty, human development, the location of the indigenous population, the degree of marginalization, and urban crime were used, based on official data, but on published cartography and available scales.

The study is not comparative, it is rather complementary and clarifying. The analysis is qualitative and has ethnography as a central element, and cartography, conflicts and social risks as complementary elements, considering the variables of the operative definition on the interstices. One limitation ${ }^{3}$ is that cartography with municipal or location data is minimal and the definition of conflict spaces is not very precise.

\section{The Place of the Study}

The territory of the United Mexican States (1.9 million $\mathrm{km}^{2}$ ) has a border (4.3 thousand $\mathrm{km}$ ) with three countries and coasts (9.9 thousand $\mathrm{km}$ ) towards the Pacific, Atlantic and Caribbean oceans; it is mountainous due to two mountain ranges: north-south and east-west volcanic axis; high (over 3 thousand meters) and deep ravines. It has high plateaus in the north and center, as well as important valleys, in addition to a limestone plateau in the southeast called the Yucatan Peninsula.

Politically, it is a representative, federal-presidential, democratic and secular republic, made up of 31 states and Mexico City (with 16 mayors). It is divided into 2,463 municipalities that are free, sovereign and autonomous in their internal regime; with their own legislative and executive powers and that have the obligation to provide all the basic public services required by the population.

There are 119 million inhabitants in the country (average density: 61 inhabitants $/ \mathrm{km}^{2}$ ); $49 \%$ live in urban areas (50,000 and more inhabitants), 22\% in semi-rural areas (2,500 to 50,000 inhabitants) and 29\% in rural areas (less than 2,500 inhabitants). It is a multiethnic and multicultural nation, with more than 60 indigenous languages and their variants (6.6\% speakers); with original indigenous groups (10.1\%) and Afro-descendants/Afro-Mexicans (1.3\%) who live mainly in isolated rural areas and a majority of the population called mestizos or non-indigenous people who speak Spanish.

The Mexican economy is free market capitalist, integrated into world organizations. Trade is regulated by economic agreements with other countries. One of the main sources of revenue comes from money sent by migrants to their families. The service sector contributes more than $70 \%$ of the GDP; industry $26 \%$; and agriculture $4 \%$. The latter occupies $18 \%$ of the labor force; industry $24 \%$; and services $58 \%$. Some sectors that stand out are tourism, the automotive industry, oil and energy. The last 20 years, the cultivation and 
transportation of drugs has been the focus of attention, with a strong impact on the structure, socio-political organization and economy of the country (Inegi, 2017; INPI, 2017).

\section{Historical Constraints}

A fundamental condition to consider is that the geopolitics of the country is dynamic, that is, the construction of the limits and the territorial space under the control of the State are in a continuous process of change and transformation. For example, in the 1824 Constitution Act there are 19 states and four territories. In the 1857 Constitution there are 23 states and one territory. In the 1917 Constitution there are 29 states, two territories and the Federal District. In practically one hundred years, Mexico lost half of its territory; the territories of the Estado de Mexico and Puebla were reduced; Baja California, Sonora and Sinaloa, Nuevo León, Coahuila, Yucatán were divided; and the states of Guerrero, Morelos, Hidalgo, Campeche and Quintana Roo were created. See details in the maps in Figure 1.

\section{FIGURE 1 \\ DYNAMICS AND CHANGES IN THE TERRITORIAL, NATIONAL AND STATE DISTRIBUTION OF MEXICO}

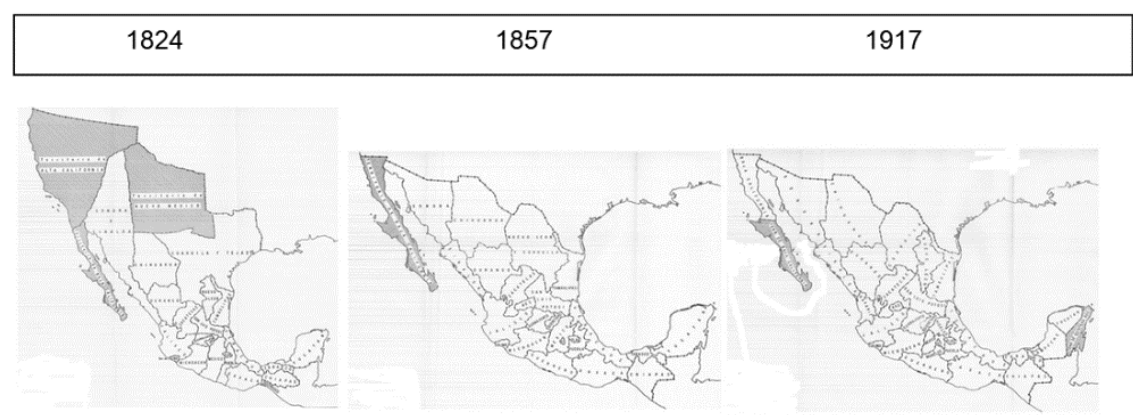

Source: (O'Gorman, 1994: 72, 137 and 161). Historia de las divisiones territoriales de México (History of Mexico's territorial divisions).

The municipality is currently the unit of territorial organization; each is a free, administrative, political and governmental institution. It has its possible origin in the Mesoamerican calpullis, later poured into cabildos, town halls during the Conquest and New Spain; and finally in the municipality, in the unsettled Mexico. They have been classified in metropolitan, urban, semi-urban or rural municipalities. Some states have five municipalities, while others, like Oaxaca, have more than 500. The municipal territorial extension varies from $4.5 \mathrm{~km}^{2}$ to more than $50 \mathrm{~km}^{2}$; some are densely populated like Iztapalapa, in Mexico City, with 1.8 million inhabitants, while the small ones can have less than 40 thousand. For example, in the state of Oaxaca there are 30 municipalities with less than 500 inhabitants.

The important thing about both of these precedents (about the state and the municipality) is to demonstrate that there is a dynamic in the formation of the state and that the tendency has been towards the reduction of states and, above all, towards municipal division. This means that the boundaries are dynamic; they can move forward, backward, or even leave some spaces without being clearly assigned to one or another municipality or state. Thus, for example, the reduction of the Estado de México and Puebla gave rise to the emergence of the states of Guerrero, Hidalgo and Morelos; the division of Yucatan territory gave rise to the states of Campeche, Yucatan and Quintana Roo. For the creation of a new municipality, in the Estado de Mexico in 1996 it was a requirement: (a) to have more than forty thousand inhabitants; (b) share a historical and cultural past; or (c) have a territorial demarcation that forms a continuous geographical unit. However, each state may have some different requirements for the formation of new municipalities. 


\section{PARTICIPANT OBSERVATION}

\section{The Solis Valley}

This case will be described and analyzed more broadly, as it was the one that exposed what we later called the interstice.

For over three years we conducted a series of field investigations in this region (Martínez and Saucedo, 1991; Martínez et al., 1993; Saucedo, Chávez, Ríos and Martínez, 1996; Saucedo, Chávez and Vi-lla, 2002). In the Mexican central highlands there is a rural region, marginal, with subsistence agriculture. The population is considered mestizo and some indigenous communities are of the Mazahua and Otomi ethnicities. The most notorious problems are poverty, infant mortality, malnutrition, alcoholism, migration, low schooling and limited access to public services.

We worked in a group of 12 rural communities in a valley that for at least two centuries and until 1936 was a housing area, whose land was expropriated and distributed among the peasants of the valley and neighboring communities. During our interviews, people remembered that when the hacienda was there, and even much later, that region was a passage of cattle, which they stole during the afternoon or night in the nearby states (Querétaro, Michoacán and Guanajuato), to be sold the next morning in the slaughterhouses of Mexico City. In 1960 there were still communes and ranches that did not pay taxes due to their indecision to belong to one or another of the neighboring states. Quite clearly, people also described the ecological decay from the 1970s onwards: the tree-lined river where people went swimming or fishing. By 1990 it was contaminated with sewage and no trees were left.

The ejidatarios (people with rights to ejidal lands) and small farmers had fragmented their lands, inheriting them to the next generations, to the extent that some only had a quarter, half or one hectare; and very few had larger plots. So most of the land was devoted to producing corn for family consumption or barter, and much of it ended up with local hoarders. A good part of the year the peasants migrated to the urban centers of Toluca, Querétaro or Mexico City; the lesser ones went to the northern states (Sinaloa, Sonora and Chihuahua) or to the United States.

The few men who stayed in the communities or returned to the valley on weekends feared arrest or extortion by some authority. The women described how their husbands, accused of any crime, were taken from their homes and held in police cars or nearby jails for their relatives to post "bail". The cost went up, depending on where the money was delivered, and no one wanted to go to jail in the city of Toluca, because it meant more money and, above all, that they would spend days or weeks in jail.

In 1992, a group of women decided to manage access to a milk program for their communities in the municipal capital of Temascalcingo; those in charge of the program warned them that they could take the milk to any community except Santa Rosa. The women of that community were upset and demanded an explanation. The response was that "that community is the last one in the municipality and if you take the milk there, the inhabitants of the communities in the state of Querétaro, which is next door, will be the ones to take advantage of the milk". They complained again, since the neighboring houses on the Querétaro side were inhabited by their cousins, brothers, uncles, among others. Due to the pressure, the municipal employees had to take the milk to that community.

When we returned to Santa Rosa and walked through the state limits, to our surprise, we found that the poles that you are on were only on the side of the Estado de Mexico, so the neighboring houses did not have service either. In this case, the explanation was that in one state the Comision Federal de Electricidad provided that service, while in the other it was the Companía de Luz y Fuerza del Centro. ${ }^{4}$

The community mentioned is located to the east, on the hillside, so from there you can see the entire valley of Solis, named after the old hacienda that bears that name. The valley is crossed by the Lerma River, contaminated by residual discharges. To the west of the valley there is another great hill, belonging in its majority to the State of Michoacan; following the highway to the north is the city of Amealco, in the State of Queretaro. Thus, we realized that the valley was within the limits of three states.

As we toured the communities bordering Michoacán with the Estado de México, we witnessed a dispute between the Ministry of Health and the IMSS-Solidaridad. ${ }^{5}$ Both institutions sought to provide services to the same community. Each one held meetings with the inhabitants to convince them to accept their services. 
Why? The reason was that this community was the most accessible and close to their respective medical units. The institution that was not chosen by the community would have to seek out other communities. Four years later (1994), the IMSS-Solidaridad built the new Rural Unit in a region with dispersed families and communities, far away and difficult to access.

\section{The Tarahumara Mountain Range}

It is located in the northwest of Mexico, in the southwestern region of the state of Chihuahua: it borders the states of Sonora, Sinaloa and Durango. In this region of $64,000 \mathrm{~km}^{2}$ live four dispersed indigenous groups (Tarahumaras, Tepehuanes, Pimas and Guarijíos). There, not only is the devastation of natural resources and the poverty of its inhabitants notorious, but also the constant activity of drug trafficking (Saucedo and Aguilar, 2016; Saucedo, Gardea, Sánchez, Mojica and Ramírez, 2012).

People remember that the landowner Terrazas declared that "the state of Chihuahua was on his ranch, not his ranch in Chihuahua", since he owned 1.5 million hectares (ha). The Ibarra y Vega chiefdom controlled another million, located between the states of Sonora and Chihuahua. Between 1960 and 1966 there were 100 hectares of properties owned by one owner, dedicated to livestock; some 300 landowners had an average of 20,000 hectares each. On the contrary, 100,000 ejidatarios owned 4.5 million hectares, with plots of 45 hectares each, and 50,000 peasants had no land. During the twentieth century, several caciques (leader of an indigenous community) occupied, dispossessed and expelled the Indian populations from the land, by any means, deception or violence. The defenders of the ranchers, like Anselmo Enriquez, Luis Mendoza and Francisco Luján, among others, were murdered by the mountain businessmen. There are demands for land have been going on for many years, especially since the formation of the ejidos in 1930 or 1940, and to this day some people are illegally occupying indigenous lands, which they continue to violate. ${ }^{6}$ Many of the abuses by caciques/businessmen have occurred under the support/commissioning of local, state, and federal authorities. In particular, we remember the government of Miguel Alemán, who made the concession of one million hectares to the company Bosques de Chihuahua, which on the one hand obtained benefits and on the other denied the rights of the peasants to their position. Years later, as former president, Alemán bought the Babícora ranch in that same region, to sell it a few months later.

Every year, in the Tarahumara mountains, they raise the alarm about the possible hunger situation of the indigenous people. In 1986 all the inhabitants of the community of Mocorichi de Abajo (Urique) died from a "strange disease". This community of guarijíos was located to the north and on the border with Sonora. In that same year, the indigenous Tepehuanos of the town of Baborigame, in the south of the state, announced the risk of hunger due to the loss of their crops (Giner, 1987). Since 2000, news of drug trafficking violence in the municipality and city of Guadalupe y Calvo, near the borders of Sonora, Sinaloa, and Durango, has been constant; for this reason many indigenous people have migrated to the city of Chihuahua, fleeing hunger, dispossession, exploitation, and violence.

The health services, although they do an important job and it is a strength, every year they lack sufficient personnel to cover the medical units because these professionals fear for their lives. So it is not uncommon for the units to go, for weeks or months, without service. For example, in 2011 the hospital in Baborigame was not opened due to lack of equipment and because no one wanted to go to work there. The Tepehuanos sent requests to the president of the republic to put it into service, alluding to the fact that it was only a white elephant (Indigenous leader, 2011).

The Pima region of Chihuahua, adjacent to the state of Sonora, has been in a permanent state of violence since 2010 due to conflicts between drug trafficking groups. In this region is the community of Yepachi, in the municipality of Temósachic, where it is common to find burned cars and houses, or traces of gunfire in the housing networks. For one or two years, the adult men had to run into the mountains, being chased by armed groups from the state of Sonora (only 20 minutes away), which entered the community every weekend. In the indigenous shelter-school of that community, half of the children were orphans and some only knew that their parents were in the bush (which could mean they were in hiding or dead). ${ }^{7}$ It should be added that this region is a natural protected area, however, mining has been reactivated; it is also the passage of the federal highway between the state of Chihuahua and the city of Hermosillo, Sonora. 
The Sierra Tarahumara is a space shared by several indigenous groups with mestizo populations, and there can be located simultaneous conflicts; that is, there are several nuclei and different dynamics. In the north, the Pimas are being persecuted and killed by drug traffickers and groups from Sonora; the Guarijíos in the northeast are being abandoned by municipal authorities and are suffering from hunger. In the south, the Tepehuanes are driven out by drug-trafficking violence; and in the center, the Tarahumara, who are the majority of the indigenous population, are exploited, their lands taken away or invaded, to mention a few problems.

\section{Geopolitical Interstices, Operational Definition}

Based on the two ethnographies, we developed a preliminary definition of the interstices. They are spaces between the limits of the federal or municipal entities. The interstices of greater instability and risk are located where three or more entities converge; difficult to access due to geographical accidents and with scarce resources, of little value or difficult to exploit. They are spaces with damage or deterioration ecological (deforestation or pollution); rural areas, principally, where de facto powers develop (chieftains, drug trafficking), abuses of power and conflicts; low population density, marginal groups and ethnic minorities, and the absence or discretionality of administrative and judicial power. Although they may have economic conditions, it has been preferred to call them geopolitical interstices because the responsibility of political and administrative authorities is considered more important.

\section{TERRITORIAL DYNAMICS}

\section{Cartography of Mexican Territory}

The following maps show the Mexican political division with the distribution of indicators by locality/municipality: social lag, food poverty, degree of marginalization according to the National Evaluation Commission (Coneval), the National Population Council (Conapo); human development index and presence of indigenous language speakers according to the National Institute of Statistics and Geography (Inegi).

In Figure 2, 20 possible interstices can be easily identified throughout Mexican territory; that is, spaces where the condition of the encounter or collinearity of three or more federal entities is met. For example, Chihuahua has three interstices: one between Sonora-Sinaloa, another between Sinaloa-Durango and one more between Durango-Coahuila. Thus, successively, others can be identified.

In Figure 3 the locations are located, according to the degree of social lag, at the level of the locality. The darker the space, the greater the gap (Coneval, 2005). Two regions stand out on this map: the Sierra Tarahumara and the region between Jalisco, Nayarit, Sinaloa, Durango and Zacatecas (the original maps are in color).

Figure 4 shows the population in a situation of food poverty at the municipal level for the year 2005 . The darkest areas are those of greatest poverty; the regions mentioned again stand out, as well as the adjacent limits between Veracruz, San Luis Potosí and Hidalgo; and practically the entire limit of Veracruz with the other states. In the Pacific region, the map shows food poverty on the borders of Michoacán, Guerrero and the Estado de México, as well as in the states of Guerrero, Oaxaca and Chiapas.

Figure 5 shows the degree of marginalization by state and municipality for 2010 . The darkest areas are those with the greatest marginalization (Conapo, 2010). The distribution pattern of food poverty is almost equal to the degree of marginalization.

Figure 6 shows the human development index at the municipal level (United Nations Development Program, UNDP). The darkest areas correspond to the lowest level of development.

Figure 7 uses two indicators: the indigenous-language speaking population and the degree of marginalization (Conapo, 2010). The highly marginalized communities are darker. 
FIGURE 2

MEXICAN REPUBLIC

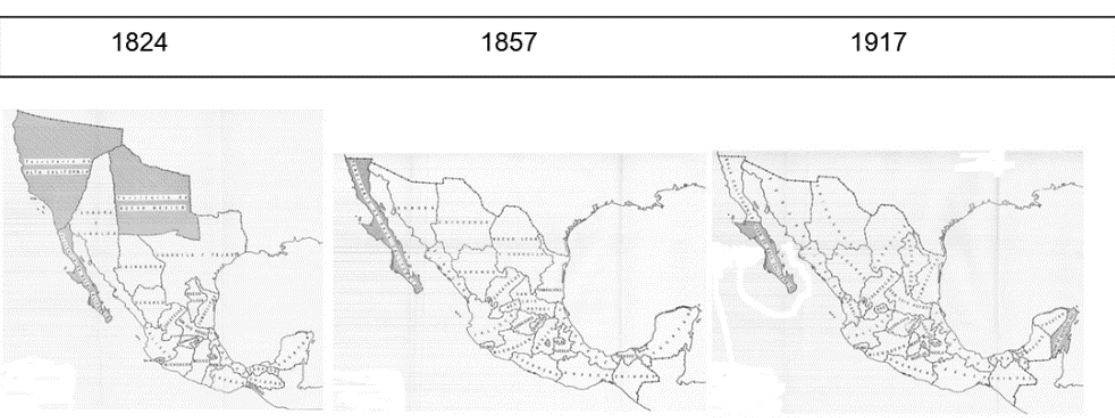

Source: Coneval estimates based on the II Population and Housing Count 2005 and ENIJH 2006.

FIGURE 3

DEGREE OF SOCIAL BACKWARDNESS AT THE LOCAL LEVEL

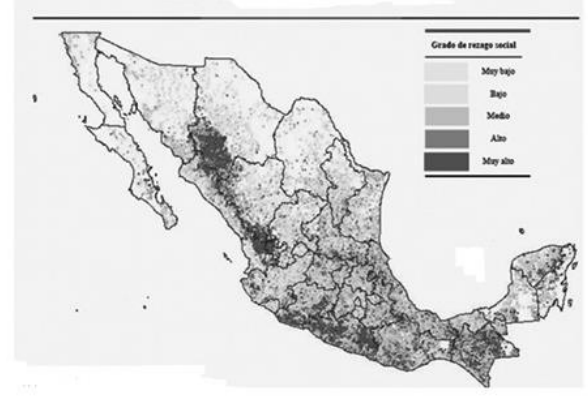

Source: Coneval estimates based on the II Population and Housing Count 2005 and ENIJH 2006.

FIGURE 4

PERCENTAGE OF POPULATION IN FOOD POVERTY AT THE MUNICIPAL LEVEL, 2005

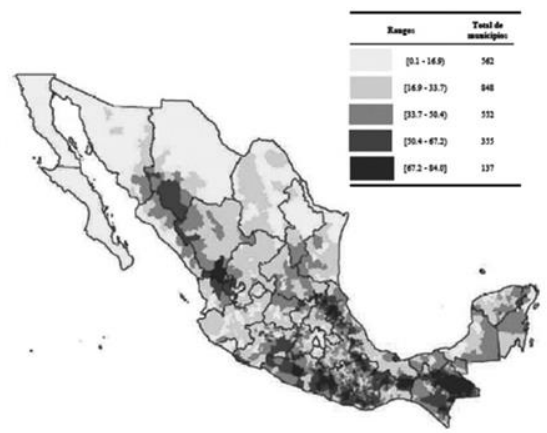

Source: Coneval estimates based on the II Population and Housing Count 2005 and ENIJH 2006. 


\section{FIGURE 5}

\section{MARGINALIZATION INDEX BY STATE AND MUNICIPALITY, 2010}

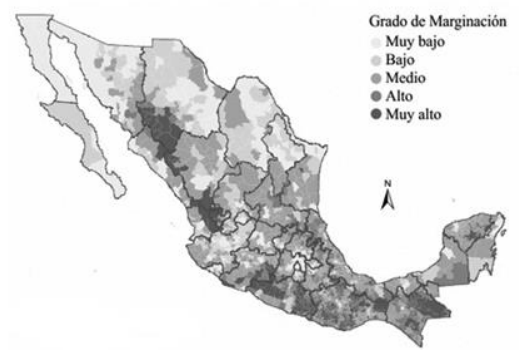

Source: Conapo, electronic database Mexico, 2011.

\section{CONFLICTING GEOPOLITICAL INTERSTICES}

\section{Borderline Conflicts}

While prior agreements are needed to determine territorial boundaries for the creation of new municipalities and states, despite of them have occurred important disputes, such as the famous case of El Chamizal, on the border with the United States of America, which lasted almost a hundred years (1884 to 1964). And in more recent years it was reported that the southern border of Mexico was 465 meters inside the territory of Guatemala (Prensa Libre, 2011). In the interior of the country, in 2013 there were 11 states involved in six widespread territorial border conflicts: Guerrero, Oaxaca, Chiapas, Yucatan, Quintana Roo, Campeche, Tlaxcala, Puebla, Nayarit, Jalisco and Colima. Geographical, social, cultural, economic and electoral issues were at stake in these conflicts. The dimension of these spaces goes from $400 \mathrm{~km}$ to thousands in dispute, as in the case of Quintana Roo, which maintains the legal struggle for $4,810 \mathrm{~km}^{2}$ of land, which Campeche argues belongs to it; while Yucatan reclaims 5,400 $\mathrm{km}^{2}$. Oaxaca intended to extend its territory over Chiapas by some 180,000 hectares (Reyes; Romero y Briseño, 2013).

\section{FIGURE 6 MUNICIPAL HUMAN DEVELOPMENT INDEX IN MEXICO}

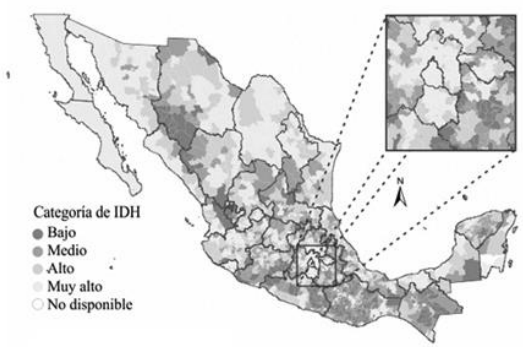

Source: UNDP. 


\section{FIGURE 7 \\ MARGINALIZATION AND PRESENCE OF INDIGENOUS LANGUAGE SPEAKERS}

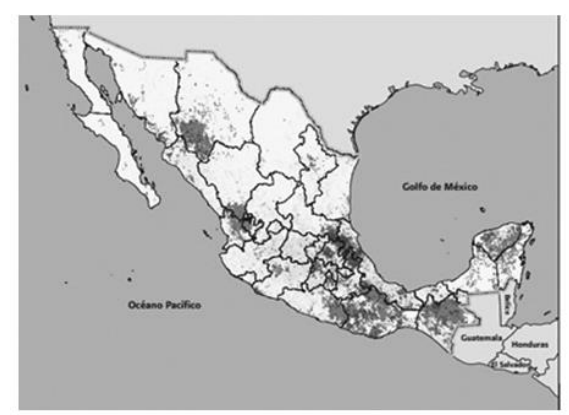

Source: UNDP. Source: Conapo estimates, based on Inegi, National Population and Housing Census 2010.

\section{JOURNALISTIC CHRONICLES OF SOME CASES OF TERRITORIAL DISPUTE}

Negotiations between the governments of the Estado de México and Hidalgo on the border conflict in San José Piedra Gorda have become bogged down, causing tension among the ejidatarios and keeping them in "guard" [...] There is real concern in the municipality of Tepeji del Río, there is fear among neighbors because of outbreaks of violence and insecurity... (Jiménez, 2003).

The territorial dispute of Quintana Roo against its two neighboring states began in 1996, when the Congress of Campeche created the Municipality of Calakmul and annexed a strip of Quintana Roo territory, a measure that also turned another portion of that entity into Yucatan territory (Machuca, 2013).

From 2006 to 2012

[...] border conflict: Authorities from Uriangato and Moroleón (Guanajuato) defend agreements with the governor and engage in a verbal confrontation territorial conflicts between Moroleón and Uriangato are being ignited [...].

[...] In the first municipality, members of the city council complain about affectations to the urban furniture, such as signs that give identity to the streets, on the part of Uriangatense residents and in the latter, for their part, they will create a collegiate body for territorial affairs in the town hall (Olvera, 2014).

\section{Agrarian Conflicts}

The "peasant organizations assure that there are close to five thousand agrarian conflicts, the same ones that are a real powder keg in 31 states of the country, including the Federal District. Only one is saved: Aguascalientes" (Méndez, 2013).

The abandonment of the countryside, where 6 out of 10 poor Mexicans live, favors violence due to agrarian conflicts, which in some cases have been going on for more than 40 years. The invasion of land, the lack of definition of territorial limits and the lack of juridical certainty in land tenure are some of the pending issues that generate social instability.

According to the Documentary Memory of the Program for Social Services in Rural Areas (Cosomer), from 2006 to 2012, 949 cases were resolved for the benefit of 107,436 farmers. The number of hectares in dispute was 322,662 in 27 states, which represented the payment of 3,794 million 991,973 pesos in compensation. In other cases, the government has paid for the land and the problems of litigation continue (Méndez, 2013). Situations have also occurred, such as in the state of Durango, where the ejidatarios of the 
municipality of Topia, at the request of the Ministry of Agrarian, Territorial and Urban Development (Sedatu), donated 2,687 hectares to the neighboring ejido of "Sal si puedes" in 2016, to end a conflict that had lasted more than 40 years; in exchange Sedatu promised to give them 18 million pesos, but that never happened (Maldonado, 2018).

In the conflict between Chiapas and Oaxaca, due to the interests of Chiapan officials in the ZoqueChimalapa territory, expressions such as: "In our ancestral territories belonging to the Zapotec, Mixe and Chinantec indigenous peoples, neither now nor ever have they been bordering on that entity. Likewise coincide, the oral tradition and basic documentation only register our belonging to the Viceroyalty of New Spain and the state of Oaxaca, never to the captaincy of Guatemala or the state of Chiapas". In the name of their governments and municipalities, the municipal presidents announced the decision to undertake the defense of their territory in the face of "the excessive pretension of the government of Chiapas to want to vary the historical limits that we have physically and materially had since the viceroyalty" (Reyes, Romero y Briseño, 2013).

\section{Socio-Environmental Conflicts}

In Mexico, there are at least 420 socio-environmental conflicts, most of them related to mining, energy and water, which threaten the ecological balance and the social fabric, according to Victor Toledo, a researcher at UNAM. ${ }^{8}$ In just one and a half years, this number grew dramatically, as 280 conflicts had been documented and the number rose. It is mainly the indigenous communities that are affected. In the cases presented in Oaxaca and Chihuahua, the resistance has gone from being local to regional (Enciso and Muñoz, 2003). From 2009 to 2011, 95 socio-environmental conflicts were identified in 22 states, but mainly in the central-western and southern regions of the country, in the states of Oaxaca, Morelos, the Estado de Mexico and Jalisco. The causes were water, agricultural land, protected natural areas, forests, hills and wetlands. The most frequent affectations were destruction, contamination and dispossession. The main reasons for these conflicts are economic and political. The former are linked to processes of development and expansion of capital, privatization; the latter are related to imposition, corruption, the change of role of the state and local struggles for power (Paz, 2014; Paz, 2012). In the case of these conflicts, since there is no mapping of them that could precisely define the relationship between the territory in conflict and the interstice, we can only point out in the sense of our hypothesis: that the risk of socio-environmental conflicts occurring in the interstices is higher. In order to prove this, it would be necessary to map and describe the social, economic and political actors involved in the conflict.

This can be shown in the cases presented below.

The Huasteca Potosina has been devastated: not even the tenth pair remains from the original one, in the last twenty years about 270,000 hectares of forests, jungles and even ecological reserves have disappeared. $94 \%$ of the forests were devastated to create an agricultural zone that did not yield what was expected. The great hydraulic work that would supply the irrigation district is paralyzed and unfinished. Pujal Coy was the most ambitious irrigated agricultural development project in Latin America (Ochoa, 2003).

The project included an area of 720,000 hectares: part of the east of San Luis Potosi, south of Tamaulipas and north of Veracruz. ${ }^{9}$

They are holding works in the border conflict zone. The mayor of Cihuatlán Colima promised to stop hydraulic works being carried out on the ejido [...] Tension is growing between Jalisco and Colima due to the border conflict. Guadalajara, Jalisco, June 29. Some six police patrols from Manzanillo and the state of Colima entered the municipality of Cihuatlán, Jalisco, and installed a roadblock in El Rebalse (a community disputed by both entities), denounced the mayor of that town, Enrique González Gómez. This incursion increased the tension between both states due to a boundary conflict (González y Partida, 2007). 


\section{Agrarian Conflicts and Indigenous Regions}

We cannot affirm that all agrarian conflicts occur in the interstices, the hypothesis is that there is a greater risk of them occurring in those spaces. The case of indigenous populations is particularly clear, since their location has been constantly delimited and supervised by federal institutions, especially by the Commission for the Development of Indigenous Peoples. Likewise, the location of their regions is constantly being mapped.

Then the location of agrarian conflicts in the regions, in relation to the interstices, will be more or less evident with the comparison of the maps. Some possible reasons for the conflicts are the relationship with other groups, caciques, drug trafficking, for their diverse forms of land tenure, among others. It should be added that the indigenous population is located in 22 states; that there are more than 60 groups with a different language or with differences even within the same group, and that the indigenous regions are not limited to one municipality or one state, but most likely overlap with them.

In order to have a dimension of the conflicts, let's see some data. The Institutional Revolutionary Party speaks of 30 thousand conflicts (Pérez, 2002) of independent peasant organizations, the National Coordination "Plan de Ayala" (CNPA) considers 500 (Enciso, 2016). The federal government recognizes 422,14 of which it considers to be red hot spots because they have been going on for more than 20 years and because they have caused confrontations, injuries and deaths. The latter represent around $3.1 \%$ of the total number of recognized conflicts (López, 2005).

Violent clashes on the borders between Zacatecas and Durango have not been ruled out, so he asked the federal government to resolve the conflict through legal means, since "we do not want another Acteal". This Monday is the first anniversary of the occupation by Tepehuano Indians from Durango in the Zacatecas ejidos of Bernalejo de la Sierra and Pajaritos, in the municipality of Valparaiso. The dispute is for 5,400 hectares of forest (Valadéz, 2002)

The conflict that began a year ago between the people of Durango and Zacatecas over the ejido of Bernalejo has the indigenous people enduring hunger, and the children face problems of malnutrition. The ejidatarios are willing to plant in the "forbidden" land even if they are confronted by the Tepehuanos. They also denounce that the few cattle they have left have been stolen, which worsens the situation of the Indigenous (Maldonado, 2005).

According to the Commission for Dialogue with Indigenous Peoples (CDPIN):

[...] the 335 conflicts involving indigenous peoples and communities have been documented thanks to the registration process that begins with an exhaustive review in the print media and the contents of different news websites [...] the main disagreements are over mining and land tenure projects; Chiapas tops the list with 63, and Aguascalientes, Tamaulipas and NL are exempt. The oldest conflict dates back to 1928 [...]The indigenous Tohono O'odham ${ }^{10}$ of Sonora, located in the municipalities of Caborca, Saric, Altar, and Plutarco Elias Calles, demand the recognition and titling of the territory that belongs to them, and oppose the construction of a border wall with the United States, pointing out that it would divide the ancestral lands of this binational ethnic group that has significant sites of its cultural identity on both sides, in addition to affecting the ecosystem of the area (Becerril, 2018).

\section{Armed Conflicts}

Nor is it easy to say that major armed conflicts have occurred in these geopolitical interstices; each would have to be tested within its own context. These are a few examples, but we will not analyze them. Again, in the sense of the hypothesis, we can point out that there is more risk of the emergence of armed conflicts in the interstices. 
In 1965 a group of teachers, peasants and students attacked the military barracks in Ciudad Madera, Chihuahua; this marked the beginning of modern Mexican guerrillas (Liga Comunista 23 de Septiembre). This conflict was the response against the caciques Ibarra and Vega, among others, who since 1943 had turned the Chihuahua Sierra into a lawless land, sown with terror, desolation, misery, abandonment, exploitation and all kinds of abuses; but also into a commercial monopoly, for livestock and forestry exports with the support of local, state and federal governments (López, 2009; Cedena, 2016: 1). Journalist Dora Villanueva denounces that this municipality is practically governed by the drug cartels; there are complaints about the devastation of the mines, violence, extortion and kidnapping (Coria, 2015).

In the state of Guerrero, during the 1970s, the guerilla movement of professors Lucio Cabañas and Genaro Vázquez emerged, along with the National Civic Revolutionary Association and the Party of the Poor (in Atoyac de Álvarez). ${ }^{11}$ The Popular Revolutionary Army emerged in 1996 and since then has operated in the regions of Costa Grande, Centro, Montaña and Costa Chica in Guerrero, as well as in the Loxicha region and the Central Valleys of Oaxaca. Some of its cells move towards the valley of Mexico and the Huasteca region, in the border area of the states of Hidalgo, Veracruz and Puebla (Coria, 2015).

The Zapatista Army of National Liberation of 1994 has antecedents in Monterrey, Nuevo Leon, with the organization of the Forces of National Liberation of 1969. It was considered part of the subversive movement and had influence in the states of Nuevo León, Puebla, Veracruz, Tabasco and Chiapas. In the latter state, their presence and control is recognized in the municipalities of Las Margaritas and Ocosingo, in the state of Chiapas, near the border with Guatemala (Coria, 2015).

\section{Drug Trafficking Groups or Cartels}

Of the predominant groups, some cover very large areas. Those that particularly call attention are the Gulf Cartel, in the states of Tamaulipas and Veracruz; and in the Pacific, in the state of Sonora; the Sinaloa group and the groups located in Jalisco, Michoacán and Guerrero, to mention a few. A case that is widely known is the so-called "golden triangle", which corresponds to the space where the states of Chihuahua, Sinaloa and Durango border each other. In these large areas there are also certain conditions, although we will talk about them later.

In the south of the Estado de México, in the areas bordering the states of Guerrero and Michoacán, Tlatlaya, Amatepec, San Simón of Guerrero, Luvianos, Otzoloapan and Valle de Bravo, there are 80 vacancies for doctors and nurses that have not been filled for months, or even years. No one wants to go to work there because of the insecurity in the area; the main reason is the risk of being forced by armed groups to leave to treat the wounded in the clashes between criminal groups (Davila, 2018).

\section{OTHER PROBABLE INTERSTICES}

Two other cases that should be considered as possible geopolitical interstices are the Sierra Norte de Puebla and the Valle del Mezquital in Hidalgo. One is near the limits of the states of Hidalgo-Veracruz, and the other towards the state of Querétaro-México. One is a semi-desert, and the other is a forest with high rainfall; one has a high population density and the other has a very low one. Both pose important crises in their relations between indigenous and mestizo people, exploitation, marginalization, migration and ecological conflicts.

In the border regions there are several areas of great complexity, but we will only point them out in a general way: the region of Tijuana in Baja California, the border of Coahuila-Nuevo León-Tamaulipas; in the Pacific all of the state of Colima, and in the southeast the complex and historical area of ChetumalBelice, which until the end of the 1980s was the entrance to the merchandise (fayuca) with which the Tepito neighborhood was supplied, in Mexico City.

Can interstices be developed or exist in cities, between streets, avenues or neighborhoods where mayor's offices are located? In these spaces, urban problems should be evident: ${ }^{12}$ the lack of surveillance, traffic lights, maintenance and patching services, garbage collection, increased incidence of informal commerce, street violence or drug sales, among others. An evaluation of crime in Mexico City published its distribution in three months (Figure 8). 


\section{FIGURE 8 \\ DENSITY OF HOMICIDE REPORTS IN THE CDMX 200920152016}
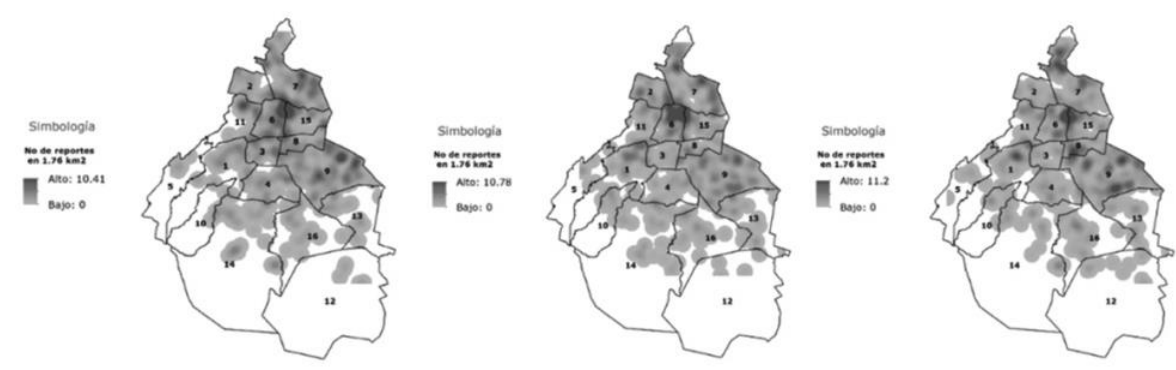

Source: Mexico evaluates. Center for the Analysis of Public Policy, 2018.

The lines correspond to the political division and the color intensity represents a greater or lesser density of reports. It is evident that there is a region where the highest density is concentrated, in the three moments; and it coincides in a space of adjacency between three and four mayoralties. It is probable that this region also has a higher population density. It should be noted that in Mexico City there is a unified police force under a single command, so there should be no difficulties in coordinating the different municipalities. However, it is interesting to note that this coincides with the existence of three or more administrative and political units.

\section{CONCLUSIONS}

There are a number of regions that are highly vulnerable to social conflicts and that originate from state borders. The conflicts between Zacatecas, Durango and Nayarit are a case in point, as is the problem between Quintana Roo and Campeche. However, it is the state of Veracruz that could have the highest rate of conflicts, due to its proximity to seven states. It is clear that the condition of this state facilitates the emergence and development of groups of factual power, such as drug trafficking or others. In this way, prevention is made possible throughout the country, considering to regions where social conflicts and health risks may be accentuated due to their socio-historical condition. It is also true that the orography of certain regions can contribute to the social risks of the settled populations in the western-eastern and southern Sierra Madre.

The situation of the indigenous communities is an aspect that we would like to highlight and that we consider to be of greater importance, since their location corresponds to a great extent to the interstices between them, to the regions with little accessibility, especially to the mountain areas, and to the social indicators of risk. The Tarahumara, Huichol, the Huastecan regions of Veracruz, Hidalgo and San Luis Potosi, the Mixtecan regions of Guerrero and Oaxaca, the highlands of Chiapas and the Mayan region stand out.

Further disaggregation of data, as well as in the observation and analysis units, is necessary for the examination of risks and interstices. If the state unit is used, the values are diluted in territories as large as the state of Chihuahua; on the other hand, the municipality is a better unit and the ejido, urban or rural basic geostatistical areas (AGEB), and the locality could also be considered. In the cities, the delegation or police stations are not enough; the neighborhoods could also function. Due to the increasing quantity and quality of information, it will be possible to carry out more precise analyses.

In this work it was first proposed that the boundaries between states and municipalities are dynamic, which has been demonstrated. The hypothesis that geopolitical interstices can exist in any state seems plausible to us and we think that this has also been demonstrated to some extent. We consider that geographical accidents and economic conditions are important, but we still think that political will and responsibility are unavoidable.

Faced with this geopolitical complex where we assume that everything is under processes and relations, regulated or established, coordinated and structured socially, economically and politically, we find that it 
is possible to identify geopolitical interstices between communities, municipalities and states in the national geography, where the relations between them are very different.

The dynamics between people and social groups are more dynamic and they are under greater social, economic and political instability. This manifests itself in a greater risk of conflict, social backwardness, marginalization, food poverty, and lack of human development.

The assumptions that we consider as conditions in the preliminary definition for the emergence and development of these interstices seem to be correct. Interstices arise and develop by:

a) the dynamics and changes in the territory; b) little or difficult access to these regions; c) lack, deterioration or depletion of their natural resources or that they do not represent economic and developmental benefit; that their exploitation is not affordable for trade or formal industry under municipal or state regulations; d) lack of coordination among institutions; e) inequity (intentional or not) in the distribution of resources, goods and services; f) lack of political will and responsibility to address intermunicipal or state conflicts; g) the presence of marginalized, vulnerable social groups; h) gradual deterioration and ecological disaster; i) a power and control vacuum; $j$ ) historical and social facts that demonstrate the instability of this space. The indicators of instability will be the history of state and municipal boundary disputes, social conflicts over certain natural resources, among others; $\mathrm{k}$ ) The interstices with the highest levels of risk are located mainly on state and municipal boundaries, especially those interstices that are between three or more municipalities or states.

Although geopolitical interstices seem to be "no man's land" or powerless spaces because they do not represent an economic or political interest for the State, on the contrary, they can be favorable spaces for the development of local powers, caciques, drug trafficking and capital. In other words, it can be assumed that interstices facilitate the development of capitals and groups that evade and corrupt municipal, state or even federal laws or regulations. The hypothesis can be reformulated: it seems that these spaces are historically necessary for the expansion of capital (and power groups), if this is true, it can be predicted that these spaces occur in any country, and even between countries.

Finally, we will try to formalize the concept, adding that the interstices can be classified into border, state, municipal or mixed interstices. It is not a metric concept, since we do not intend to measure space or time, however, it can be argued that the greater the number of units involved (states or municipalities) the greater the complexity. It could be useful to classify the interstices into agrarian, armed, ecological, ethnic or other. By their nature, interstices are not well defined; rather, this is a condition of them; but what we can assume is that some are developing and others are becoming extinct.

Thus, the general conclusion is that these spaces arise and develop due to the lack of political will, responsibility and coordination within the municipality and between municipalities; within the state and between states. One question that remains to be answered is: Why are there interstices without conflict? Of course, the best way is to analyze each one, and make sure that in reality there are no conflicts. In general, we could assume that in that interstice there is no power vacuum, that there is an infrastructure for communication, that there is inter-state coordination, that the terrain does not make communication difficult or facilitate isolation, and that the municipality or state has sufficient control. Two cases that stand out are Aguascalientes, without any conflict, and San Luis Potosí, which, although it borders nine states, apparently only has problems with Tamaulipas and Veracruz. A separate case is the Estado de México.

\section{ACKNOWLEDGEMENTS}

The Spanish version was published in Saucedo-Arteaga, G.J. (2019, September-December). Legislative Journal of Social Studies and Public Opinion, 12(26), 73-105.

Translated \& edited by American Publishing Services (https://americanpublishingservices.com/). 


\section{ENDNOTES}

1. Diminished ability of a person or group to anticipate, cope with, and resist the effects of natural or humancaused hazards and to recover from them. It is almost always associated with poverty, but people living in isolation, insecurity and defenselessness are also vulnerable to risk, trauma or pressure (Rivera, 2012).

2. This perspective has not been abandoned; in fact, there are important analysts/journalists, such as the American Robert D. Kaplan and the British Tim Marshall, who consider geographical factors to be decisive.

3. Another limitation is not having considered the ejido, which is of great importance in Mexico, and which is made up of a set of goods and rights given to ejidal (forms of social tenure of land in the Mexican countryside) property.

4. Both were state companies, but with different administration.

5. Both are health institutions, for primary care in rural and marginal areas.

6. In two years there have been nine homicides of indigenous leaders, such as Julián Carrillo, who were protesting against logging and mining companies and organized crime groups in the Tarahumara Sierra (Animal político, 29/10/2018).

7. In 2011 we stopped activities with the adults in that region because of the risk involved in bringing them together at the shelter (Saucedo).

8. National Autonomous University of Mexico.

9. A work of 40 years. At http://pulsoslp.com.mx/2015/07/18/pujal-coy-una- obra-de-40-anos/

10. Also known as Pueblo Papago.

11. And recently the disappearance of the students of the Escuela Normal de Ayotzinapa and the executions in Tlatlaya, on the border between the states of Guerrero and the State of Mexico (Coria, 2015).

12. And the most appropriate variables should be identified.

\section{REFERENCES}

Barth, F. (2004). Ecologic Relationships of Ethnic Groups in Swat, North Pakistan. American Anthropologist. https://doi.org/10.1525/ aa.1956.58.6.02a00080

Becerril, A. (2018, January 7). 335 indigenous disputes; live with families in 29 states. Excelsior (online). Retrieved from https://www.excelsior.com.mx/nacional/2018/01/07/1212041

Cedena. (2016). Center of Documentation of the Armed Movements. Mexico City. Retrieved from http://www.cedema.org/index. php?ver=show\&country=9\&countryname=Mexico

Comas, J. (1975). Manuel Gamio. Anthology. Mexico: Instituto de Investigaciones Económicas, Universidad Nacional Autónoma de México.

Conapo. (2010). Marginalization Index. Mexico. Retrieved from http://www.conapo.gob.mx/ES/CONAPO/Indice_de_Marginacion_por_Loca-lity_2010

Coneval. (2005). Social lagging index. Retrieved from https://www.coneval.org.mx/Medicion/IRS/Paginas/Indice-de-rezago-so- cial-2005.aspx

Coria, C. (2015, September 24). Madera City, caught in the fight of the posters. Excélsior (online).

Retrieved from https:// www.excelsior.com.mx/nacional/2015/09/24/1047465

Dávila, I. (2018, November 24). Groups of criminals, leave the south of the state of Mexico without doctors. La Jornada (online). Retrieved from https://www.jornada.com.mx/2018/11/24/estados/ 027n2est

De la Peña, G. (1997). Regional studies and social anthropology in Mexico. In P. Pérez-Herrero (Ed.), Región e historia en México (1700-1850): Methods of regional analysis (pp. 123-162). Mexico: Instituto Mora/UAM.

Enciso, A. (2016, February 10). There are 420 socio-environmental conflicts in Mexico: Researcher. $L a$ Jornada (online). Retrieved from http://www.jornada.unam.mx/2016/02/10/sociedad/ 038n1soc

Enciso, A., \& Muñoz, P. (2003, February 19). Champion groups warn of the risk of red lights exploding on the field. La Jornada (online). Retrieved from http://www.jornada.unam.mx/2003/02/19/008n1pol.php?origen=index.html 
Free Press. (2011, October 24). Guatemala maintains that Mexico moved its territorial limit without consultation. Free Press. Retrieved from http://www.americaeconomia.com/politicasociedad/politica/guatemala-sostiene-que-mexico-movio-su-limite-territorial-without-consultation

García-Acosta, V. (2005). El riesgo como construcción social y la construcción social de riesgos. Disrespect: Social Science Journal. https://doi.org/10.29340/19.1042

Giner, A. (1987, September 18). The tragedy of Mocorichi, municipality of Uruachi. The Chihuahua Herald.

González, V., \& Partida, J. (2007, November 7). Tension between Colima and Jalisco for alleged violation of agreement. La Jornada (online). Retrieved from https://www.jornada.com.mx/2007/11/07/ index.php?section=stados\&article=039n1est

Indigenous leader. (2011). No doctors. Baborigame, Guadalupe y Calvo, Chihuahua, Mexico.

Inegi. (2017). Statistical and geographic yearbook of the United States Mexico Aguascalientes. Retrieved from http://internet.contenidos.ine- gi.org.mx/contents/products/prod_serv/contents/english/ bvinegi/products/new_estruc/AEGEUM_2017/702825097912.pdf

INI. (1993). Indigenous regions of Mexico, proposed by the Instituto Nacional Indigenista. Mexico.

INPI. (2017). Socioeconomic indicators of the indigenous peoples of Mexico. Mexico. Retrieved from https://www.gob.mx/inpi/articulos/indicadores-socioeconomicos-de-los-pueblos-indigenas-demexi- co-2015-116128

Jiménez, V. (2003, November 7). The border conflict between Hidalgo and the State of Mexico continues. Milenio Diario, p.12. Retrieved from http://www.pa.gob.mx/noticias/2003/noviembre/110703.htm\#HIDALGO

León-Hernández, E. (2016). Critical Geography. Space, Social and Geopolitical Theory. Mexico: Ithaca/UNAM.

López-Bárcenas, F. (2005). Territorios indígenas y conflictos agrarios en México (Indigenous territories and agrarian conflicts in Mexico). Estudios Agrarios (pp. 85-118). Mexico: Procuraduría Agraria. Retrieved from http://www.pa.gob.mx/publica/rev_32/ lopez.pdf

López-Limón, A. (2009). The Wooden Martyrs, Rebellion in the State of Chihuahua, Mexico 1965. Chihuahua. Retrieved from http://la-convencionsinaloa.blogspot.com/2009/09/los-martires-demadera- rebeldia-en-el.html

Machuca-Martinez, G. (2013, November 7). SCJN, resolved in favor of Campeche constitutional controversy of territorial limits. Maya Sin Fronteras (online). Retrieved from http://www.mayasinfronteras.org/2013/11/scjn-resoluted-in-favor-of-campeche-with-throversy-constitutional-ofterritorial-limits/

Maldonado, S. (2005, May 17). Agrarian conflicts between peasants from Durango and Zacatecas begin again. La Jornada (online).

Maldonado, S. (2018, November 24). Ejidatarios of Durango exigen to Sedatu the payment of $\$ 18$ million. La Jornada (online). Retrieved from https://www.jornada.com.mx/2018/11/25/estados/ $027 \mathrm{n} 2 \mathrm{est}$

Martínez, H. (1991). Mothers' Perceptions about childhood diarrhoea in rural Mexico. J Diarrhoea Dis Res, 9(3), 235-243.

Martínez-Salgado, H., Martínez-Andrade, G.O., Contreras-Pérez, J., Saucedo-Arteaga, G., Huerta-Pérez, J., Ramos, R.I., . . Chávez-Villasana, A. (1993). Experiences in co-municipal participation to promote nutrition education. Salud Pública de México, 6(35), 673-681.

Mendez, E. (2013, March 10). Agrarian conflicts hit 31 entities of the Republic. Excelsior. Retrieved from https://www. excelsior.com.mx/2013/03/10/888233

Oliver-Smith, A. (2002). Theorizing Disasters: Nature, Culture, Power. Culture and Catastrophe: The Anthropology of Disaster.

Olvera, C. (2014, August 31). Territorial boundaries lead to disagreement. Correo Newspaper (online).

Paz-Salinas, M.F. (2012). Socio-environmental conflicts and civil society alternatives. In D. Tetreault, H. Ochoa-García, \& E. Hernández- González (Coords.), Conflictos ambientales. Guadalajara: ITESO. Retrieved from http://hdl.handle.net/11117/425 
Paz-Salinas, M.F. (2014). Socio-environmental conflicts in Mexico. Contributions from social anthropology. In M.F. Paz-Salinas \& N. Risdell (Coords.), Conflictos socioambientales en México, ¿Qué está en disputa? Mexico: Regional Center for Multidisciplinary Research, UNAM/Porrúa. Retrieved from https://horizontescomunitarios.files.wordpress.com/2016/09/conflictos-socioambientales.pdf

Pérez-Urbina, M. (2002, June 11). There are 30 thousand agrarian conflicts in the country, warns the CNC. La Jornada (online). Retrieved from http://www.jornada.unam.mx/2002/06/11/013n1pol.php?origen=politica. html

Reyes, J-P., Romero, G., \& Briseño, P. (2013, April 7). In struggle for land 11 states dispute boundaries. Excelsior (online). Retrieved from www.excelsior.com.mx/nacional/2013/04/07/892633

Rivera-Duiz, N. (2012). The definition and measurement of social vulnerability. A normative approach. Geographic Research.

Saucedo-Arteaga, G., \& Aguilar-Salinas, C. (2016). Maize/beans/ko-rhyme in the Raramuri. In M. del R. Jáquez Rosas (Coord.), Patrimonio gastronómico de Chihuahua (pp. 181-200). Chihuahua: Chihuahua State Government.

Saucedo-Arteaga, G., Chávez-Villanueva, A., Rios-Espinosa, E., \& Martínez-Salgado, H. (1996). Anthropology, epidemiology and nutrition. Mexico: National Institute of Nutrition "Salvador Zubirán".

Saucedo-Arteaga, G., Chávez-Villasana, A., \& Villa-Romero, A. (2002). Program for the detectionattention of malnutrition in a rural population of the Mexican highlands. Antropoformas, 6, 4553.

Saucedo-Arteaga, G., Gardea, N., Sánchez, R., Mojica, A., \& Ramírez, A. (2012). Hunger present in the memory and culture of the indigenous people of the Tarahumara mountain range. Alter Magazine, Enfoques Críticos, 6, 71-85. Retrieved from https://static1.squarespace.com/static/552c00efe4b0cdec4ea42d9f/t/55785d56e4b0884eaa70036d/ 1433951574141/ALTER6+-+07.pdf

Tetreault, D., Ochoa-Garcia, H., \& Hernández-González, E. (Coords.) (2012). Socio-environmental conflicts and alternatives in civil society. Guadalajara: ITESO.

Valadéz-Rodríguez, A. (2002, February 24). Community members of Durango expel community members from two Zacatecan towns 200 ejidatarios. La Jornada (online). Retrieved from http://www.jornada. unam.mx/2002/02/24/035n1est.php?origen=estados.html

Viqueira, C. (2001). El enfoque regional en antropología (C. Viqueira, ed.) (Collection). Mexico: Universidad Iberoamericana. 